\title{
Characteristics, Impacts and Risks of Dammed Lakes Induced by Debris Flows at the Wenchuan Earthquake Areas
}

\author{
Yonggang Ge ${ }^{1 *}$, Xingzhang Chen ${ }^{2}$, Jianqi Zhuang ${ }^{3}$, Xinghua Zhu ${ }^{3}$ \\ ${ }^{1}$ Key Laboratory of Mountain Hazards and Earth Surface Processes, Institute of Mountain Hazards and \\ Environment, Chinese Academy of Sciences, Chengdu, China \\ ${ }^{2}$ School of Environment and Resources, Southwest University of Science and Technology, Mianyang, China \\ ${ }^{3}$ College of Geology Engineering and Geomatic, Chang'an University, Xi'an, China \\ Email: ${ }^{*}$ gyg@imde.ac.cn
}

Received 13 September 2014; revised 8 October 2014; accepted 29 October 2014

Copyright (C) 2014 by authors and Scientific Research Publishing Inc.

This work is licensed under the Creative Commons Attribution International License (CC BY).

http://creativecommons.org/licenses/by/4.0/

(c) (i) Open Access

\begin{abstract}
After the Wenchuan Earthquake, many large-scale debris flows blocked rivers, generated dammed lakes, and produced outburst flood at the seriously hit areas. This paper mainly discussed the formation, outburst, impacts and risks of debris flow dammed lakes. The field investigation showed that the dammed lakes were created by debris flows from gullies and hill-slopes as well as the combination of debris flow and landslides, and also distributed along rivers step-by-step. The height of dams and the length of dammed lakes along river channel varied from $4 \mathrm{~m}$ to $18 \mathrm{~m}$ and from $400 \mathrm{~m}$ to $5000 \mathrm{~m}$, respectively, and the reservoir capacity of dammed lakes were from $1.5 \times$ $10^{5} \mathrm{~m}^{3}$ to $3 \times 10^{6} \mathrm{~m}^{3}$. Due to geomorphological impact, dammed lakes commonly partially outburst along their front of debris flow deposition dams (1/4 - 1/3 outburst) or the suture between debris flow and landslide, and hardly completely outburst. Moreover, the subsequent debris flows continuously increased the magnitude and height of dams, not only increasing the stability of a single dam, but also improving the risks of outburst flood induced by intensive rainstorm. Dammed lakes produced steep rage in the sites of dams with the $4 \%$ - $9 \%$ of slope and rapidly raised river channel in the upstream due to a mass of alluvial sediment. As a result, the landscapes of step-dams and step-lakes dominate driver channels, significantly increasing the hazards of floods. Then the hazards, impacts and risk of debris flow dammed lakes along Min River from Dujiangyan to Wenchuan were analyzed. In order to mitigate dammed lakes induced by debris flows, the identification model of debris flow blocking rivers, the process of the formation, outburst and evolvement of
\end{abstract}

${ }^{*}$ Corresponding author.

How to cite this paper: Ge, Y.G., Chen, X.Z., Zhuang, J.Q. and Zhu, X.H. (2014) Characteristics, Impacts and Risks of Dammed Lakes Induced by Debris Flows at the Wenchuan Earthquake Areas. Journal of Water Resource and Protection, 6, $1574-1588$. http://dx.doi.org/10.4236/jwarp.2014.617144 
dammed lakes, and the model of risk assessment for step-dammed lakes were strongly suggested to explore, and be used at the rivers of Min, Yuzi, Caopo, Longxi, Mianyuan, Jian, Shiting, Baishui and Jushui.

\section{Keywords}

Dammed Lakes, Debris Flows, Outburst, Impacts, Risks

\section{Introduction}

Dammed lakes are generally generated by landslides from torrential rains, earthquakes, lavas from volcanic eruptions, or ice-jams and moraines from glacier [1], and have been concerned and deeply researched to explore the mechanism of dammed lake formation, assess and predict risk, and find the technical measures for mitigating [2]-[11]. The intensive earthquakes at mountain areas generally result in a large number of geo-hazards, including landslides, rock falls, debris avalanches and debris flows, which also block rivers and create dammed lakes so as to endanger mountain environment and local inhabitants' security. The dammed lakes of Mogangling at the Dadu River and Diexi along Min River were triggered by 1786 Kangding-Luding earthquake with MS 7.75 and 1933 Diexi earthquake with MS 7.5 respectively, and attracted many researchers to discovery their mechanism [12]-[14]. The Wenchuan Earthquake in May 12, 2008, with MS 8.0, produced 40,000 - 50,000 landslides, rock falls and debris avalanches [15]-[17], which blocked river and formed 257 dammed lakes. 34 big dammed lakes were prone to outburst and endangered several million local residents' security, rescue and reconstruction [18]. In the beginning 1 month after the major shake, a lot of efforts concentrated on the treatment and mitigation of dammed lakes, especially notably the treatment of Tangjiashan Dammed Lake [2] [19]. Since then, debris flows have become the dominant geo-hazards due to a mass of loose solid materials in gullies and slopes, steep geomorphology and abundant precipitation. In the past 5 years, debris flows have occurred at over 1000 gullies or watersheds in the seriously hit areas [15], moreover, and were characterized by high-velocity, large-discharge, lager magnitude and higher frequency [20] [21]. Debris flows not only directly destroyed local environments and endanger reconstruction, but also blocked rivers, formed dammed lakes, threatened the securities of its upstream and downstream, and posed more serious hazards. This paper concentrated on formation, outburst, impacts and risks of debris flow dammed lakes to give valuable measures for mitigating.

\section{Formation of Dammed Lakes}

Investigation showed that dammed lakes are generally produced by gully debris flow, hill-slope debris flow and landslides at the seriously hit valleys after the Wenchuan Earthquake.

\subsection{Gully Debris Flows}

Since 2008, debris flows have occurred at over 1000 gullies (watersheds), whose dominating areas were less than $5 \mathrm{~km}^{2}$ (Figure 1), and become the most serious geo-hazards at Wenchuan Earthquake areas [15] [16]. Comparing to the debris flows before the Wenchuan Earthquake, the peak discharge and magnitude of debris flows increased $50 \%$ and $100 \%$ at least, respectively, due to abundant loose sediment accumulation induced by the deposits of landslides, rock falls and debris avalanches [20] [21]. High-velocity and large discharge debris flow generally delivers a mass of solid materials into mainstream instantaneously, blocks river, produces dammed lakes and outburst flood. As a result, debris flow dammed lakes often occupied in river channels where the large-scale debris flows easily occurred, for example at the rivers of Min, Mianyuan, Yazi, Jian, Jushui and Shiting. At the Wenchuan Earthquake areas, the notable dammed lakes are located at the outlets of the gullies of Mozi, Guanshan, Gaojia, Luoquanwan, Huaxi, Qipan and Hongchunalong Min River, the gullies of Xiaojia, Huangyao, Dayin and Xiezi Gully along Yuzixi River, the gullies of Wenjia, Hui, Hsaoyao and Nanmualong Mianyuan River, the gullies of Shuangyanwo and Xiangshuidong along Yazi River, and the gullies of Sancha and Shuimo along Jushui River. 


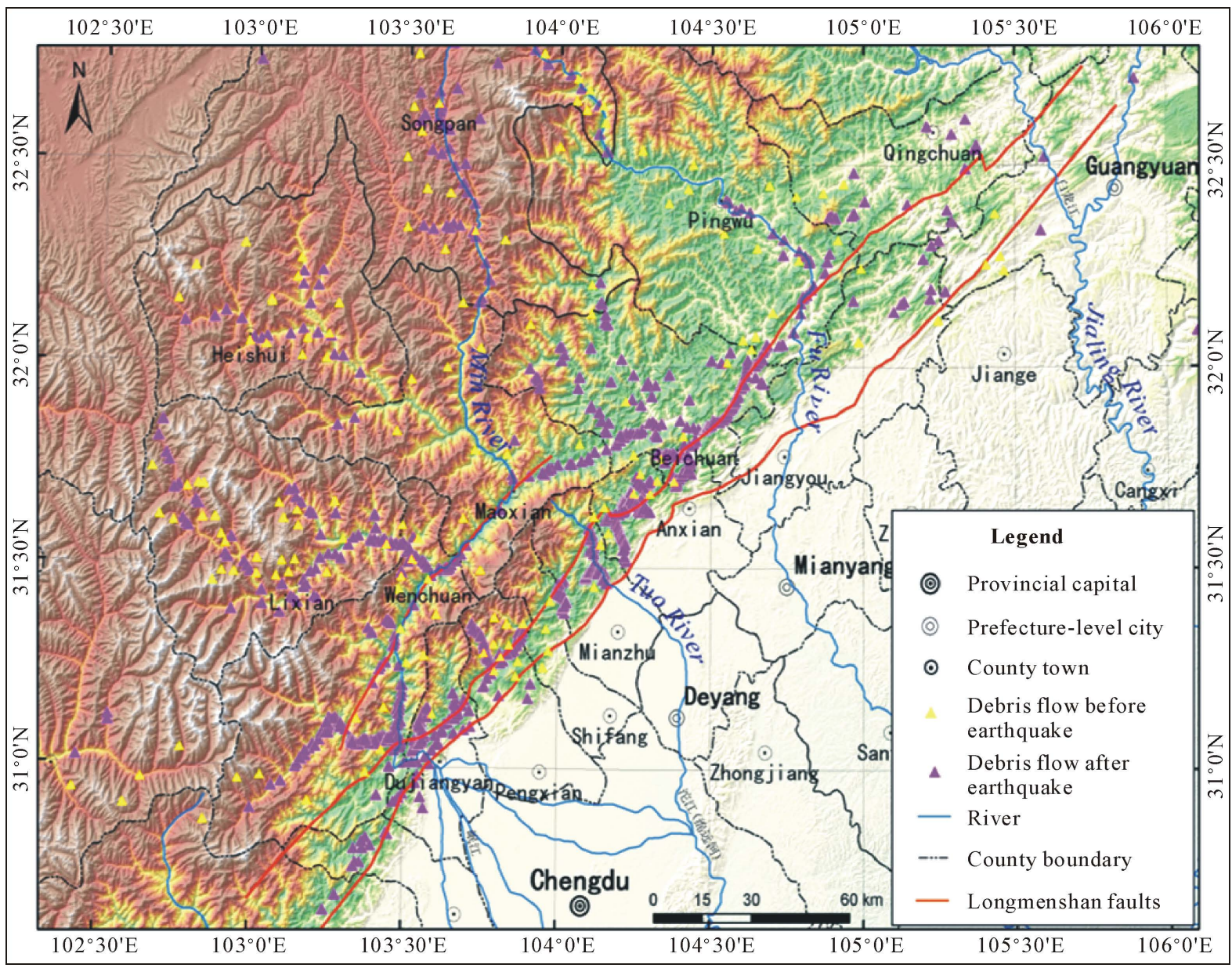

Figure 1. Debris flow gullies distribution at the Wenchuan Earthquake areas.

\subsection{Hill-Slope Debris Flow}

Hill-slope debris flows generally occur at the slopes with over $40 \%$ of slope gradient and abundant solid materials accumulation. After the Wenchuan Earthquakes, the deposits of debris avalanches and landslides provided a mass of loose solid materials and accumulated in steep slopes with $50 \%-80 \%$ slope gradient. Moreover, the height of slope accumulation ranges from $100-200 \mathrm{~m}$, which prepare adequate dynamic energy for debris flow formation. When intensive rainfall or rainstorm occurs, loose sediments are easily initiated and formed into debris flow and rapidly discharges into river, blocks it and produces dammed lakes. The dammed lakes induced by hill-slope debris flows appeared along the Rivers of Min, Jian, Yuzi and Mianyuan (Figure 2 and Figure 3).

\subsection{Debris Flow and Landslides}

Some dammed lakes were also generated by the combination of debris flow and landslides. The debris flow and landslide, located at the same section but the different bank, block river partly, respectively, so that the river is blocked completely and the dammed lake was formed, for example the Xiaogangjian dammed lake at Mianyuan River (Figure 4(a)). Meanwhile, the nearing debris flow deposit and landslide body at the same bank also can jointly block river and create dammed-lake. The landslide body occupies the partial space of the outlet of debris flow gully and increase the height and magnitude of debris flow deposition dam, moreover, the volume and stability of the whole dam is strengthened (Figure 4(b)). As a result, the dammed lake is strengthened and very difficult to outburst completely. These kind of dammed lakes majorly appear in the river section where landslides, rock falls and debris flow gullies densely distribute, for example the sections of from Yinxiu to Gengdaalong Yuzixi River and the Mianyuan River. 


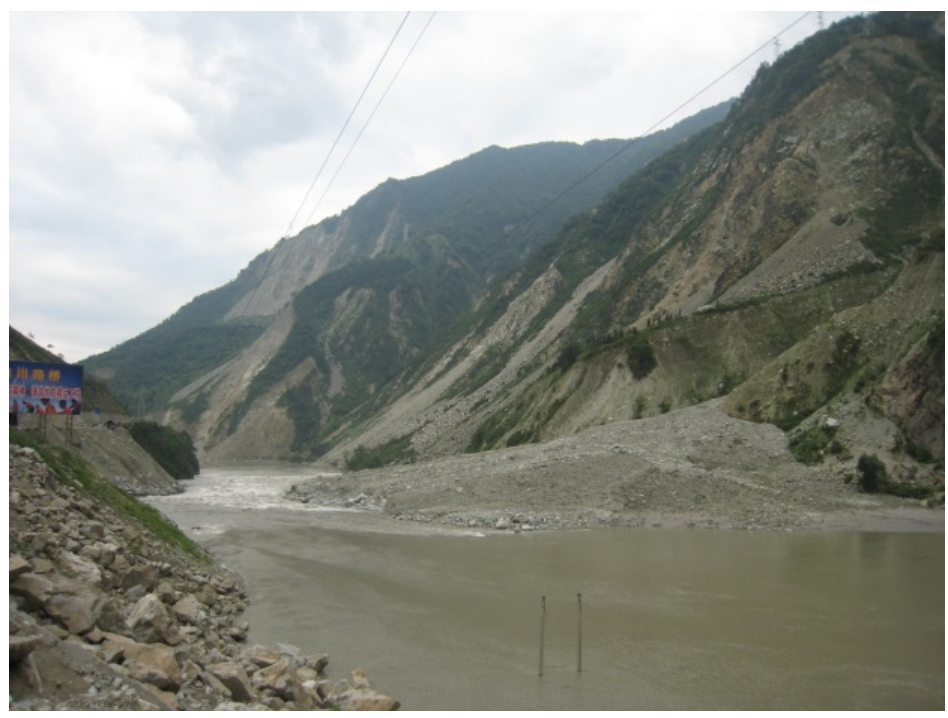

Figure 2. Dammed lakes formed by gully debris flow at Min River.

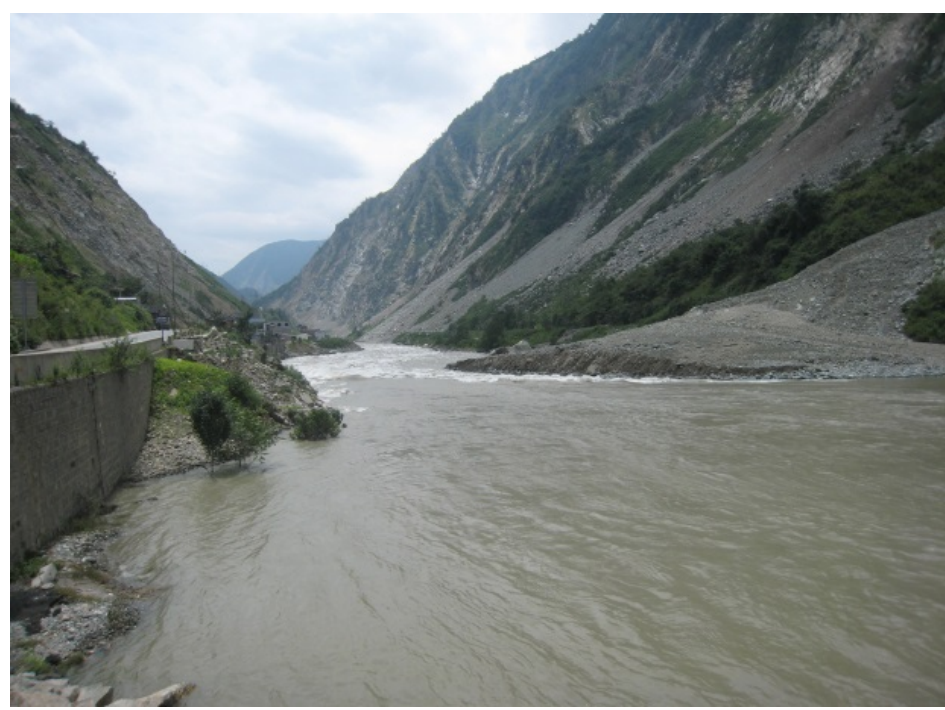

Figure 3. Dammed lakes formed by hill-slope debris flow at Min River.

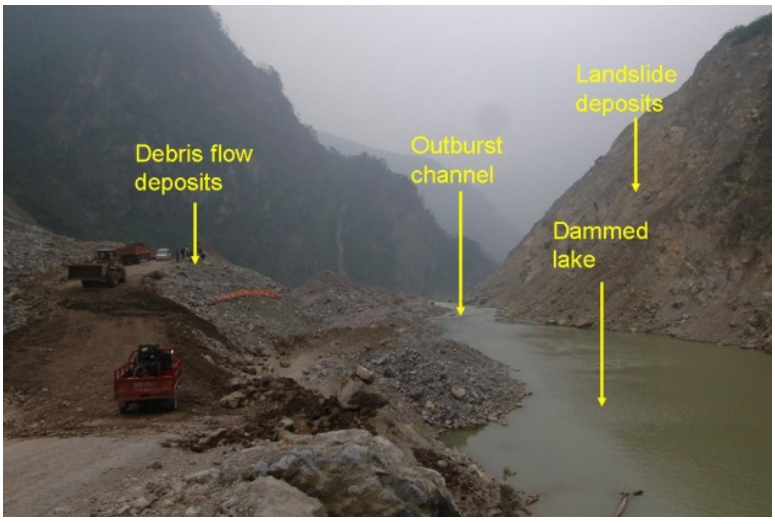

(a)

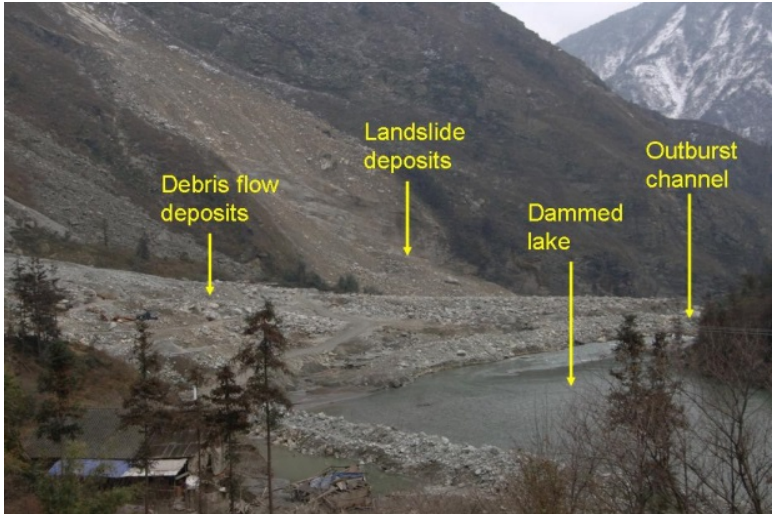

(b)

Figure 4. Dammed-lake formed by debris flow and landslide ((a) at Mianyuan River; (b) at Yuzi River). 


\section{Characteristics of Dammed Lakes}

The dammed lakes induced by debris flows are different to those by landslides, rock falls, glaciers and volcanos and these in Wenchuan Earthquake areas are characterized by their own.

\subsection{Distribution}

The distribution of debris flow dammed lakes depends on the distribution of large-scale debris flows. After the Wenchuan Earthquake, abundant loose solid materials resulted in the remarkable decrease of debris flow initiation rainfall intensity and the significant rise of discharges and magnitude of debris flow. The antecedent accumulated precipitation and 1 hourly rainfall of initiating debris flow decreased $14.8 \%-22.1 \%$ and $25.4 \%-31.6 \%$, respectively [22]. Local intensive rainfall or rainstorm often triggers multitudinous debris flows in special areas. For example, 72 debris flows occurred on Sept. 24, 2008 in Beichuan county, hundreds of debris flows took placed along Min River, Yuzi River, Longchi River and Mianyuan River in August, 2010, over 1000 debris flows occurred in the whole Wenchuan Earthquake areas. Many large debris flows blocked river and produced dammed lakes. As a result, most debris flow dammed lakes distributed step-by-step along rivers. For example, 14 dammed lakes in Min River, 13 at Yuzi River, 12 at Mianyuan River and 8 at Yazi River Upper in 2010 and 25 along Min River in 2013.

\subsection{Geomorphology}

The geomorphologic characteristics of debris flow dammed lakes are also very different to those caused by landslides, rock fall, glacial avalanche and volcanos. The related indexes of 17 debris flow dammed lakes at the Wenchuan Earthquake areas are showed in Table 1.

Table 1 expressed that the height of debris flow dam varied from $4-30 \mathrm{~m}$, much lower than those of landslide dams. The axes slope gradient of debris flow deposition dam range from $30 \%$ to $450 \%$ and the dominating are over $200 \%$. The shape, height and volume of debris flow dam were in diversity which depend on the dynamic parameters of debris flow, the geomorphology of the outlet of debris flow gullies and river channel and the sediment that was delivered into river. The slope of outburst channel was from $20 \%$ o to $90 \%$, and the majority were over $40 \%$ and much higher than those of mountainous river (5\% - 10\%). According to the height of debris flow dam and river channel slope as well as investigation data, the back water of debris flow dammed lakes generally extended 400 - $5000 \mathrm{~m}$ along river upstream and even longer and the reservoir volume of a debris flow dammed lake ranged from $0.15-6.0 \times 10^{6} \mathrm{~m}^{3}$. Therefore, debris flow dammed lakes generally generate the landscape of continuous step dams and deep lakes.

\subsection{Size Components and Stability of Dams}

Debris flow deposits, whose sizes of solid grains range from um to $10 \mathrm{~m}$, are the dominating of the dams. The investigation showed the materials with bigger than $100 \mathrm{~mm}$ and $1000 \mathrm{~mm}$ occupy $48 \%$ - 56\% and 4\% - 9\%, respectively. The test data of debris flow deposition dam samples $(<100 \mathrm{~mm})$ showed in Figure 5, and indicated great particle variation of debris flow deposits due to different material sources and their lithology. The $\mathrm{D}_{50}$ of debris flow deposits ranged from $2.1 \mathrm{~mm}-21.5 \mathrm{~mm}$. According to the calculation formula for debris flow density which was established by $\mathrm{Yu}$ [23], the density of debris flow deposits were from $1.88 \mathrm{~g} / \mathrm{cm}^{3}$ to $2.17 \mathrm{~g} / \mathrm{cm}^{3}$, and those with over $2.0 \mathrm{~g} / \mathrm{cm}^{3}$ and more than $1.95 \mathrm{~g} / \mathrm{cm}^{3}$ occupied $77.7 \%$ and $90 \%$, respectively. The high-density debris flow formed dams, which is difficult to completely outburst although their height are generally less than $20 \mathrm{~m}$ because that the deposition dam (soil) are complete saturated and no pores, with high viscosity and river flow are not enough to initiate and make debris flow dam failure to outburst. Moreover, after the Wenchuan Earthquake, landslides, rock fall, and debris avalanches provided abundant loose solid materials and the percentage of gravels and stones $(>1000 \mathrm{~mm})$ in debris flow deposits were higher than before the Earthquake. Those stones bigger $1000 \mathrm{~mm}$ of some debris flow deposition dam were about $5 \%$, which also improve the stability of the dam. Therefore, debris flow dammed lakes were difficult to outburst completely even though the dam were absolutely overflowed.

\subsection{Outburst}

Debris flow dammed lakes generally outburst partly by virtue of their shape and geomorphology. After debris 
Table 1. Geomorphology and features of debris flow dammed lakes in Wenchuan Earthquake area.

\begin{tabular}{|c|c|c|c|c|c|c|c|c|}
\hline \multirow{2}{*}{ Gully name } & \multirow{2}{*}{ Mainstream } & \multicolumn{4}{|c|}{ Dam structure } & \multirow{2}{*}{ Outburst } & \multirow{2}{*}{$\begin{array}{l}\text { Outburst } \\
\text { channel } \\
\text { slope (\%o) }\end{array}$} & \multirow{2}{*}{ Hazards } \\
\hline & & Long (m) & Wide (m) & High (m) & Slope (\%) & & & \\
\hline Wumin & Yuzixi River & 78 & 90 & $4-5$ & 190 & $\begin{array}{l}\text { Overflow and } \\
\text { outburst partly }\end{array}$ & 60 & Low \\
\hline Yinchang & Yuzixi River & 80 & 337 & $6-14$ & 230 & $\begin{array}{l}\text { Overflow and } \\
\text { outburst partly }\end{array}$ & 45 & Low \\
\hline Xiezi & Yuzixi River & 222 & 321 & $12-14$ & 450 & $\begin{array}{l}\text { Overflow and } \\
\text { outburst partly }\end{array}$ & 70 & Low \\
\hline Xiaojia & Yuzixi River & 340 & 191 & 15 & $250-270$ & $\begin{array}{l}\text { Overflow and } \\
\text { outburst partly }\end{array}$ & 80 & Low \\
\hline Wasi & Yuzixi River & 110 & 300 & $8-10$ & 231 & $\begin{array}{l}\text { Overflow and } \\
\text { outburst partly }\end{array}$ & 40 & Low \\
\hline Xiangshuidong & Baishui River & 90 & 150 & $12-13$ & 140 & $\begin{array}{l}\text { Overflow and } \\
\text { outburst partly }\end{array}$ & 90 & Low \\
\hline Huilong & Baishui River & 101 & 150 & 15 & 221 & $\begin{array}{l}\text { Overflow and } \\
\text { outburst partly }\end{array}$ & 40 & Low \\
\hline Gaojia & Min River & 230 & 230 & 15 & 200 & $\begin{array}{l}\text { Overflow and } \\
\text { outburst partly }\end{array}$ & 90 & Low \\
\hline Yinxingping & Min River & 230 & 400 & 15 & 200 & $\begin{array}{l}\text { Overflow and } \\
\text { outburst partly }\end{array}$ & 40 & Low \\
\hline Mozi-1 & Min River & 219 & 189 & 10 & 159 & $\begin{array}{l}\text { Overflow and } \\
\text { outburst partly }\end{array}$ & 20 & Low \\
\hline Guanshan Gully & Min River & 80 & 150 & $5-6$ & 280 & $\begin{array}{l}\text { Overflow and } \\
\text { outburst partly }\end{array}$ & 40 & Low \\
\hline Dahuodi-1 & Mianyuan River & 140 & 260 & 10 & 260 & $\begin{array}{l}\text { Overflow and } \\
\text { outburst partly }\end{array}$ & 40 & Low \\
\hline Dahuodi-2 & Mianyuan River & 160 & 400 & 15 & 260 & $\begin{array}{l}\text { Overflow and } \\
\text { outburst partly }\end{array}$ & 40 & Low \\
\hline Sanyanyu & Bailong River & $80-120$ & 500 & $9-10$ & $30-50$ & $\begin{array}{l}\text { Overflow and } \\
\text { outburst partly }\end{array}$ & 20 & Very high \\
\hline Xiangshui Gully & Dadu River & 350 & 400 & $9-10$ & 100 & $\begin{array}{l}\text { Overflow and } \\
\text { outburst partly }\end{array}$ & 25 & Middle \\
\hline Wada Gully & Fu River & 167 & 150 & $7-8$ & 120 & $\begin{array}{l}\text { Overflow and } \\
\text { outburst partly }\end{array}$ & $50-60$ & High \\
\hline Hongchun & Min River & 470 & 350 & $9-10$ & 200 & $\begin{array}{l}\text { Overflow and } \\
\text { outburst partly }\end{array}$ & 30 & Vey High \\
\hline Huaxi & Min River & 350 & 370 & $9-10$ & $70-90$ & $\begin{array}{l}\text { Overflow and } \\
\text { outburst partly }\end{array}$ & $25-30$ & Very high \\
\hline Qipan & Min River & 150 & 300 & $12-15$ & $30-50$ & $\begin{array}{l}\text { Overflow and } \\
\text { outburst partly }\end{array}$ & $30-35$ & High \\
\hline Shaoyao & Mianyuan & 130 & 220 & $8-10$ & 150 & $\begin{array}{l}\text { Overflow and } \\
\text { outburst partly }\end{array}$ & $30-35$ & Middle \\
\hline Wenjia & Mianyuan & 420 & 1650 & 12 & $80-100$ & $\begin{array}{l}\text { Overflow and } \\
\text { outburst partly }\end{array}$ & $15-20$ & Very high \\
\hline Sanjia & Chaping & 360 & 360 & $8-10$ & 170 & $\begin{array}{l}\text { Overflow and } \\
\text { outburst partly }\end{array}$ & $25-30$ & Low \\
\hline Hongshui & Caopo & 180 & 340 & $8-10$ & 90 & $\begin{array}{l}\text { Overflow and } \\
\text { outburst partly }\end{array}$ & 40 & Middle \\
\hline Xiangshuidong & Yazi & 150 & 300 & $15-20$ & 140 & $\begin{array}{l}\text { Overflow and } \\
\text { outburst partly }\end{array}$ & 50 & High \\
\hline
\end{tabular}




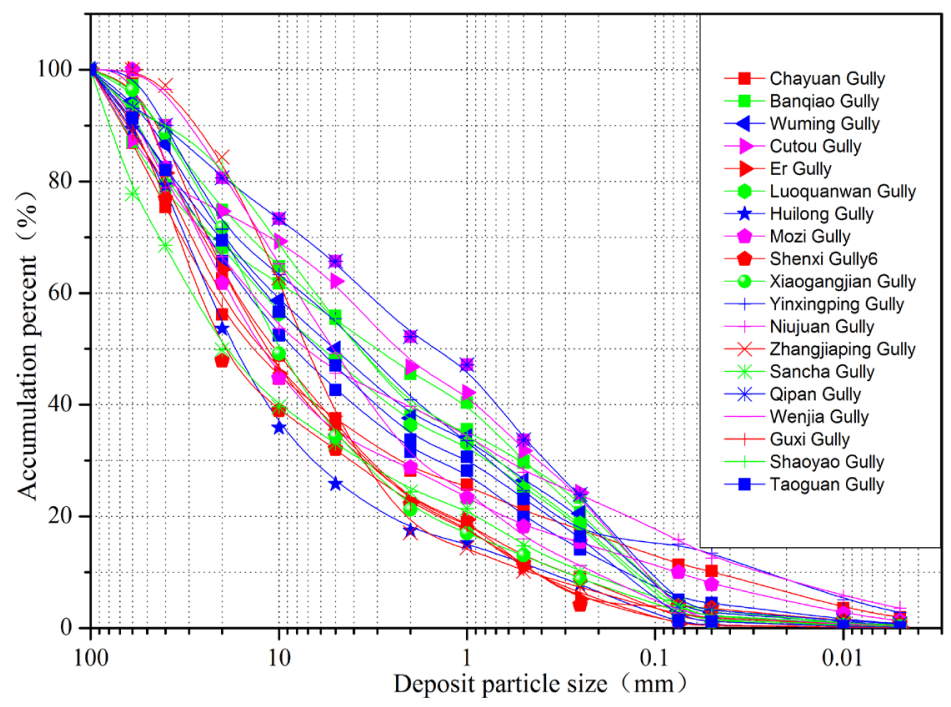

Figure 5. Particle size curve of debris flow dam at the Wenchuan Earthquake areas.

flow blocks river, the water level of dammed lakes rise rapidly, and then overflow and outburst at the lowest of debris flow dam, where are the conjunction section between debris flow deposits and the opposite bank (debris flow deposition dam front). Moreover, most debris flow dammed lakes could not outburst completely, only 1/4 or $1 / 3$ debris flow deposits were intensively eroded, deep-cut and transported to the downstream due to the impacts of lower dam height, dam structure, local geomorphology and the lower reservoir capacity of dammed lakes. The debris flow deposits composed by solid and water were only transported in very short distance but not in long distance by mainstream so that debris flow dammed lakes were very difficult to treat quickly and safely, which generally endangered the security of dam upstream. For example, the dammed-lake induced by the debris flow of Sanyanyu Gully along the Bailong River, Zhouqu, Gansu province, occurred in Aug. 8, 2010, were disposed successfully and safely by the hard efforts of the departments of hydrology and hazards over 20 days although it was only about 10 high. During this process, the scheme and methodology were altered and optimized.

\subsection{Change}

After the Wenchuan Earthquake, high-frequent debris flow induced by abundant loose solid materials resulted in the unique of debris flow dam change. Without the disturbance and treatment of the humans, debris flow continuously deposit and bury the previous debris flow deposits so that debris flow dams are strengthened in the height, volume and magnitude and become more stable. As a result, the outburst risk of a single dammed lake significant reduces. Debris flows even occur over 10 times in one year at a few watersheds or gullies. For example, the frequent debris flows of Mozi Gully, at the right bank of Min River, continuously enlarge the dam by the velocity of $1-2 \mathrm{~m} / \mathrm{a}$. the dam become more stable and the water level and submerged areas of the dammed lake gradually increase. As a result, Yiwanshui village were deeply submerged. The similar phenomena also appeared at the Gullies of Guanshan, Xiaojia, Xiangshuidong, Niumian, Shaoyao, Hui, Wenjia Gully, Yeniu, Sanchaand Xiezi.

\section{Impacts of Dammed Lakes}

The debris flow dammed lakes change and rebuild local environments including mountainous relief, river channels and sediment transportation.

\subsection{Mountainous Environment}

Frequent and large-scale debris flows remarkably change mountainous environment after the Wenchuan Earthquake. Debris flows transport quantity of solid materials and result in extreme soil erosion and vegetation de- 
stroy. Investigation data showed bare land rise from $27 \%$ to $33 \%$ due to debris flows. Then, debris flow deposits at the channel and the outlet intensively and rapidly change local geomorphology, leading to river channel narrowing, sediment deposition, and vegetation destruction. The water level of dammed lake varies from $4 \mathrm{~m}$ to 18 $\mathrm{m}$ at the range of $400 \mathrm{~m}-5000 \mathrm{~m}$, and it also further improve when debris flow dam was strengthened by next debris flows. The nearing step-dammed lakes even probably link each other, and change river into quiet lakes (sequential dammed lakes). For example, the section of Min River mainstream from Yinxiu to Luoquanwan after debris flow on August 13, 2010 and from Yingxiu to Wenchuan (55 km) after July 10, 2013.

\subsection{River Channel Change}

Frequent debris flows and dammed lakes lead to rapid change of river channel. Debris flow deposition dam firstly narrow river channel and rise river bed at the debris flow deposition areas. The investigation data showed the width of river channel generally equals to 1/3 or 1/4 of that before the Earthquake at the outlet section of debris flow gullies, for example, at the Rivers of Min, Mianyuan and Yuzi. Moreover, river channels rise from 8 to $20 \mathrm{~m}$ and even higher by virtue of the activity of a few large-scale debris flows. The whole river channel of debris flow deposition dam upstream (400 m - $5000 \mathrm{~m}$ length) also rapidly rise due to the deposition of a mass of sediment from upstream, meanwhile, they become wide. Furthermore, step-dams induced by debris flow also result in river channel curling and produce the landscape of steep ladders and deep lakes, producing abrupt change of river evolvement.

\subsection{Sediment Transportation}

Debris flow dammed lakes significantly change natural sediment delivery of rivers. Most coarse sediment including sands, pebbles, gravels and boulders and even silts generally deposit in lake bottom and continuously rise river bed and widen river channel, except for the outlet and the channel of dammed lake outburst, where coarse sediment and even river bed were eroded and transported into the lower. After flood, the suspended sediment are deposited in the upper of coarse sediment layer. Step dammed lakes generally block and store the dominant sediment in dammed lakes so that only a few suspended sediment were delivered into the lower. Intensive sediment deposition result in the rapid rise of river channel and wider river channel. For example, the water of Mianyuan River increases continuously after the Wenchuan Earthquake and endangers the highway reconstruction from Mianzhu to Mao County (the section from Hanmang town to Qingping town) (Figure 6). Researches showed only $10 \%$ sediment was delivered from this tributary into the superior tributary or mainstream, which explain the phenomena of non-rise of sediment in Min River and Jianglin River after the Wenchuan Earthquake.

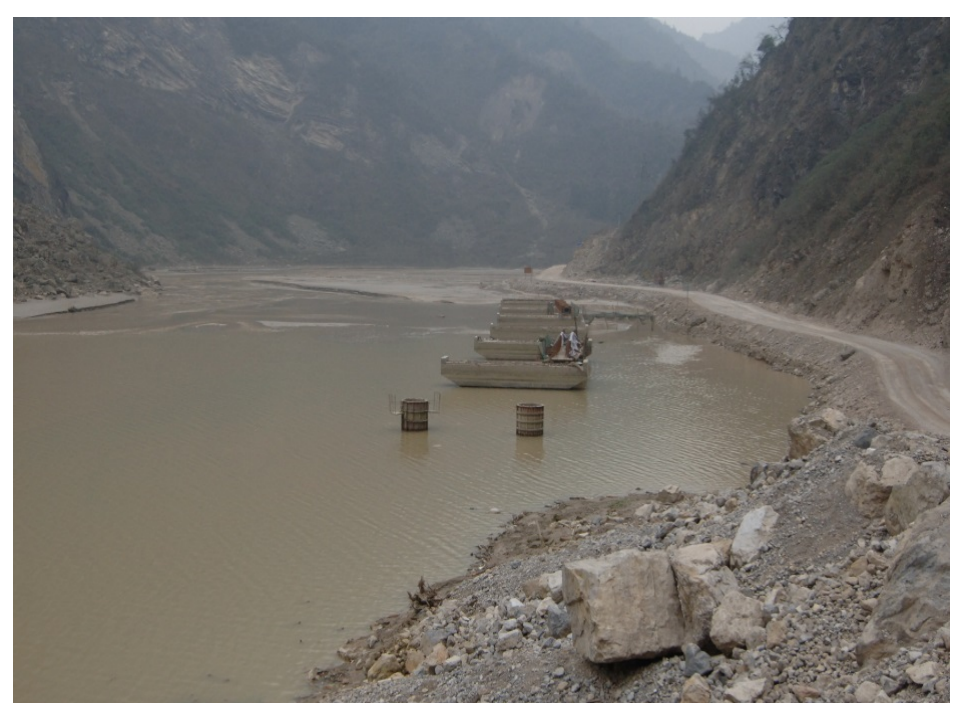

Figure 6. Dammed lakes preventing highway reconstruction at Mianyuan River. 


\section{Hazards of Dammed Lakes}

Dammed lakes, as a following hazard of debris flow, generally further deteriorate hazards and loss of debris flows, for example, destroy land and farmland, interrupt mountainous traffic, endanger villages and towns as well as destruct reconstruction.

\subsection{Land and Farmland Destruction}

Debris flow and the following dammed lakes exasperate the destruction of land and farmland, endangering the living of local peasants and destroying mountainous eco-environment. Step dammed lakes made more land and farmland along rivers and in the first terrain destructed and submerged. Investigation showed that the almost all farmlands in the drainage channel and the outlets of debris flow gullies were destructed due to debris flow bury, and dammed lakes submerged most farmlands at the Yuzi River from Yinxiu to Qicenglou Gully, at the Min River from Yinxiu to Wenchuan, at Mianyuan River from Hanwang to Qingping, at Baishui River from Longmenshan town to Dalong lake as well as at Huilong Watershed and Subaohe Watershed. Moreover, forest and shrub are destructed extensively and land degradation increase remarkably after this Earthquake, especially at drought valleys.

\subsection{Mountainous Highway}

Debris flow and the following geo-hazards imposed large hazards on mountainous traffic by destroying bridge, burying highway, scouring roadbed and submerging bridges. The highways, including from Yinxiu to Wenchuan, from Yinxiu to Gengda, from Qingping to Hanwang, from Leigu to Yuli, from Jushui to Gaochuan, are blocked and interrupted several times every year. Moreover, dammed lakes and the following outburst flood further deteriorate highway destruction. The water level of a dammed lake rapidly rises and easily submerges the highway in the upstream and interrupts local traffic. When dammed lake outburst, the torrent flood can intensively scour and erode the roadbed near the front of debris flow deposition dam and even make the roadbed completely collapse. For example, the road base from Dujiangyan to Wenchuan highway at the outlet of Luoquanwan gully an Qipan gully were ruined $500 \mathrm{~m}$ and $400 \mathrm{~m}$, respectively, which were produced by the outburst flood of dammed-lake by debris flow of Gaojia Gully and Qipan Gully (Figure 7 and Figure 8). Once regional intensive rainfall or rainstorm occurring, multitudinous debris flows and dammed lakes generally destroy highway at many sites and interrupt traffic by different means. For example, the debris flows and the following dammed lakes, occurred on Aug. 13 and 14, 2010 and July 10, 2013, interrupted the traffic from Yinxiu to Gengda and from Hanwang to Qingping.

\subsection{Mountainous Inhabitants and Reconstructions}

Debris flow and the following hazards has become the dominating threatens to mountainous inhabitants and

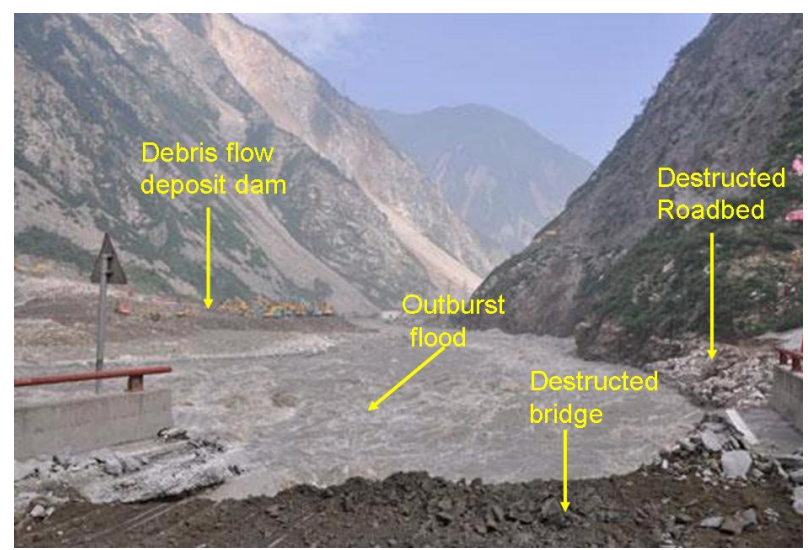

Figure 7. Outburst flood of dammed lake induced by Gaojia Gully destructed Dujiangyan-Wenchuan High-way at the outlet of Luoquanwan Gully. 


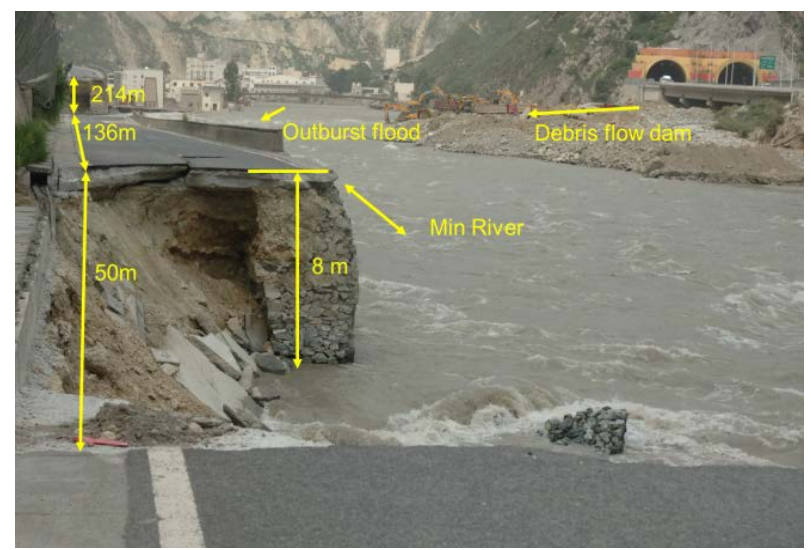

Figure 8. Outburst flood of dammed lake induced by Qipan Gully destructed Dujiangyan-Wenchuan Highway at the outlet.

reconstruction. Many peasants and reconstruction projects had better face the great hazards of debris flow and the following dammed lakes, which produced increasing risk. The dammed lake induced by the debris flow of Mozi Gully submerged Yiwanshui village of Yinxing town in 2008, and that induced by Xiaojia Gully and Xiezi Gully destroyed the reconstructing projects for tourism in 2010, including the Nanhua Tunnel of Yingxiu to Gengda. The dammed lakes, induced numerous debris flows occurred in Aug. 14, 2010, and their outburst flood submerged, buried and destructed the reconstructing projects and seriously endangered inhabitants of Qingping town. The outburst flood of the dammed lake induced by the debris flow of Hongchun Gully carried quantity of solid materials and washed out the reconstruction of Yinxiu Town. Flood and debris flow submerged the first floor and endanger the security of most areas of Yinxiu town and over 8000 persons were displaced to other safe places. Additionally, the debris flows and the following dammed lakes on July 10, 2013, destructed villages, towns and factories in the Mountainous areas of the counties of Wenchuan, Dujiangyan, Pengzhou, Shifang, Mianzhu, An, Beichuan, Mao and Pingwu.

\section{Risks of Dammed Lakes along Min River}

The section of Yingxiu to Wenchuan along Min River, a region that suffered intensive disturbance of the Wenchuan Earthquake and many geo-hazards, is always seriously damaged since 2008.

\subsection{Identification of Debris Flow Blocking River}

Almost all non-debris flow gullies changed into debris flow gullies after the Wenchuan Earthquake and over 50 debris flow gullies distributed along Min River from Yinxiu to Wenchua. Whether debris flow could block river and produce dammed lake depend on the magnitude and peak discharge of debris flow and the flux of the mainstream. Comparing to the current identification formulae of debris flow blocking river, that formed by He [24] was used to assessed the probability of dammed lake forming. It was established by analyzing the data of debris flow blocking river from Jiangjia Gully and stimulation experiment, and as following:

$$
C_{F}=\ln \left(Q_{M} / Q_{P}\right)-0.883(1-\cos \theta)^{2}-2.587 \gamma<-8.572
$$

where, $C_{F}$ indicates the comprehensive index of debris flow blocking river, $Q_{M}$ is the unit peak discharge of the main river $\left(\mathrm{m}^{3} / \mathrm{s} \cdot \mathrm{m}\right), Q_{P}$ is the maximum unit discharge of debris flow $\left(\mathrm{m}^{3} / \mathrm{s} \cdot \mathrm{m}\right), \theta$ is the junction angle of channels between debris flow gully and main river, and $\gamma$ is the mass density ratio of debris flow to the main river. In order to reflect the discrimination degree of river blocking, this equation is revised into Formula (2):

$$
K=\left|\frac{\ln \left(Q_{M} / Q_{P}\right)-0.883(1-\cos \theta)^{2}-2.587 \gamma}{-8.572}\right|
$$

where, $K$ is the probability degree of a debris flow block river. The larger the value of $K$ is, the higher the possi- 
bility of debris flow blocking will be. When the value of $K$ is over 1 or close to 1 , debris flow is likely to completely block river.

After the Wenchuan Earthquake, the magnitude and peak discharge of debris flow rise remarkably than before. The peak discharge of over 50 years of Min River $\left(2237.74 \mathrm{~m}^{3} / \mathrm{s}\right)$ and the peak discharge of debris flow triggered by the rains intensity of less $5 \%$ probability were used to discriminate the potential debris flow gullies that could block river from 29 gullies along Min River from Yinxiu to Wenchuan. The result showed in Figure 9. Debris flows from the gullies of Er, Guanshan, Mozi, Niujuan, Hongchun, Taiping and Gaodianzi were very easily to block Min River, and from the gullies of Yiwanshui, Taoguan, Futangba, Qipan, Guozhupu, Manianping and Sucun are also easily.

\subsection{Distribution of Dammed Lakes}

After the Wenchuan Earthquake, debris flows frequently and extensively occur along the Min River from Yinxiuto Chediguan. In the past over 5 years and 6 rain seasons, 25 debris flow dammed lakes ever were or are being kept in Min River, which were formed by debris flows from hill-slopes and gullies. The distribution of dammed lakes showed in Figure 10.

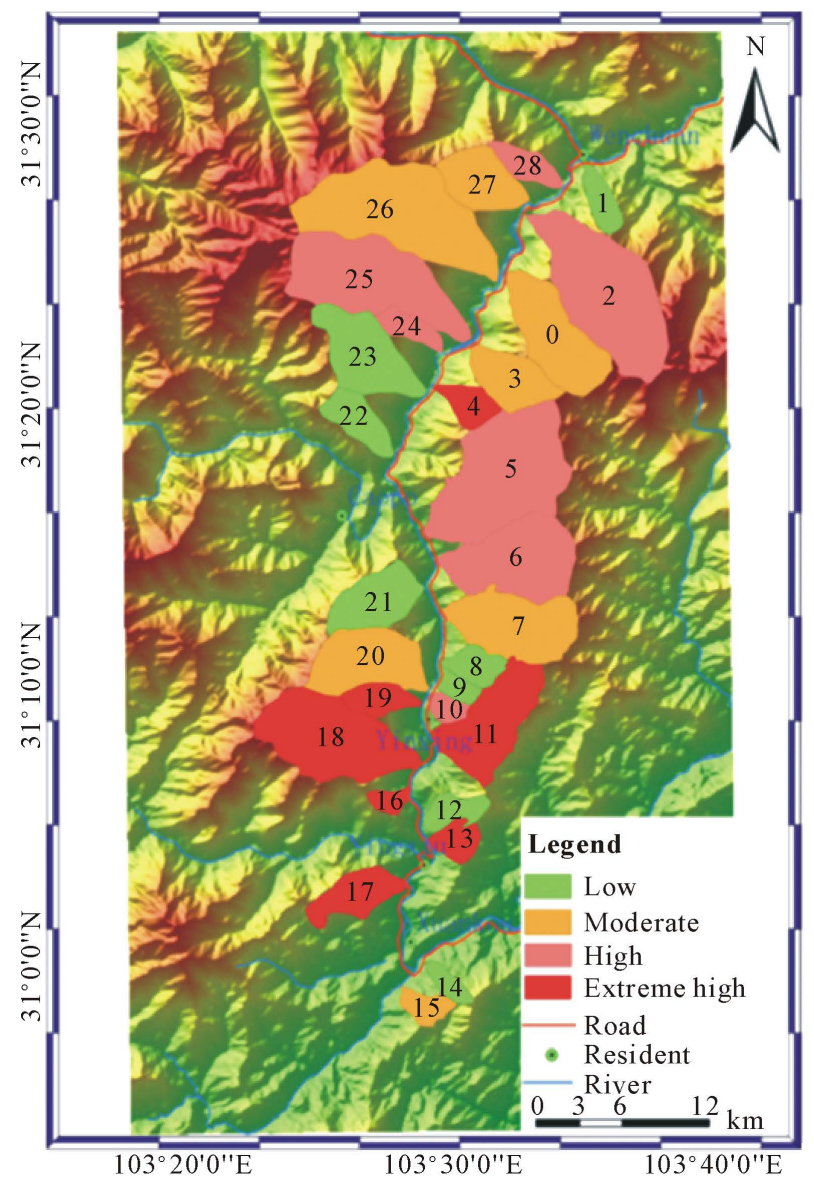

Figure 9. Probability evaluation of debris flow block river along Min River from Yinxiu to Wenchuan (Gully name: 0: Banqiao; 1: Cili; 2: Qipan; 3: Daxi; 4: Gaodianzi; 5: Taoguan; 6: Futangba; 7: Luoquanwan; 8: Yinxingping; 9: Maojiawan 10: Yiwanshui; 11: Taipingyi; 12: Shaofang; 13: Hongchun; 14: Fengdan; 15: Qianjin; 16: Guanshan; 17: Niujuan; 18: Er; 19: Mozi; 20: Yeniu; 21: Chediguan; 22: Huaxi; 23: Cutou; 24: Sucun; 25: Manianping; 26: Banzi; 27: Xinqiao; 28: Guozhupu). 


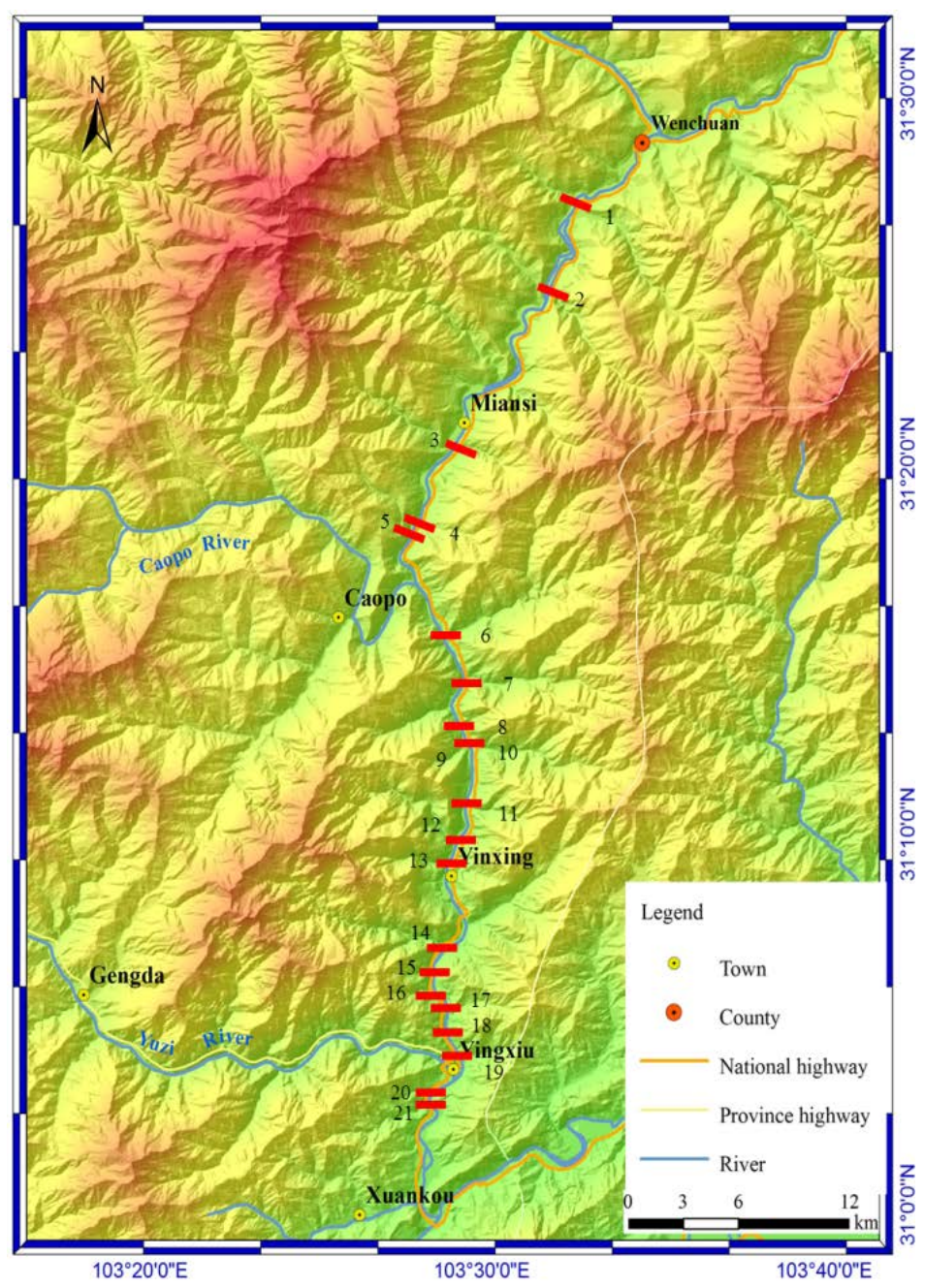

Figure 10. Dammed lakes distribution along Min River from Yinxiu to Chediguan (Gully name: 1: Qipan; 2: Banqiao; 3: Cutou; 4: Gaodianzi; 5: Huaxi; 6: Taoguan; 7: Futangba; 8: Wuming; 9: Gaojia; 10: Luoquanwan; 11: Yingxingping; 12: Yeniu; 13: Mozi-1; 14: Er; 15: Guanshan; 16: Mozi-2; 17: Mozi-3; 18: Shaofang; 19: Hongchun; 20: Zhangjiaping; 21: Niujuan.

Comparing the result of identification model, it was found that the gullies of Niujuan, Hongchun, Er, Guanshan, Mozi-1, Taipingyi, Guanshan, Gaodianzi, Qipan and were discriminated. However, the gullies of Gaojia, Shaofang, Yinxingping, Xiaojia, Mozi, Cutou, Huaxi, Luoquanwan, Banqiao, Zhangjiaping, Yeniu and other gullies were not confirmed. Moreover, some debris flows from hill-slopes were also not discriminated. Especially, the catastrophic numerous debris flows on July 10, 2013 that were triggered intense rainstorm and blocked Min River did not be identified. Therefore, this identification model could evaluate the phenomena of debris flow block river but not precisely. It is required to optimize and revise based on the deep learning on dynamic mechanism of debris flow blocking river to discover the actual process and mechanism.

\subsection{Impacts and Risk}

\subsubsection{Environmental Impacts}

Step dammed lakes of debris flow produce significant environmental impacts. They occupied and narrowed channel of Min River due to the deposit fan of debris flow, and also curve river channel. Moreover, the landscape of Min River from Yinxiu to Wenchuan changed from the narrow channel into step dams and the torrent 
flow also changed into quiet lakes. As a result, the flow velocity and the capability of sediment transportation of Min River decrease remarkably and the most sediment was deposited in the lakes, resulting in the continuous rise of river channel and the wider channel. The vertical profile of Min River channel has changed from curve line into step folds line in this section due to debris flow deposition dams. Step dammed lakes also increase the water areas of Min River, which conduce to improve the humidity of local climate and ecology recovery.

\subsubsection{Risk and Losses}

Step dammed lakes induced by debris flow take huge risk and loss to local inhabitants, reconstruction and the traffic. Dammed lakes almost submerged all farmland along the channel of Min River and debris flows also burry farmlands at gullies. Moreover, steep slope farmland had been reclaimed into forest before the Wenchuan Earthquake. Nowadays, farmland shortage seriously is endangering the living of the peasants that lived at the areas from Yinxiu town to Wenchuan. Outburst flood, especially from step dammed lakes, have become great threaten to inhabitants, for example the hazards of outburst flood from dammed lakes at the outlets of the gullies of Mozi, Wangyimao, Xiaojia, Shaofang, Hongchun, Huaxi, Cutou and Qipan. Debris flow dammed lakes destroy highway by submerging, scouring and burying and interrupt the traffic from Yinxiu to Wenchuan, as a result, the east passage to Aba region was blocked, for example at the outlet of Qipan Gully and Cheidguan. Yinxiu town was submerged by debris flow and outburst flood from Hongchun Gully (Figure 11). The debris flow materials from Hongchun Gully, $700 \times 10^{3} \mathrm{~m}^{3}$ deposited at the outlet and $400 \times 10^{3} \mathrm{~m}^{3}$ were transported into Min River, which formed a dam with the width of $350 \mathrm{~m}$, the length of $470 \mathrm{~m}$ and the height of $10 \mathrm{~m}$ at Aug 14, 2010. Debris flow deposit dam buried the highway of G213 and reconstructing bridge, and the rapid increase water of dammed lake submerged about 500 - $600 \mathrm{~m}$ highway. The debris flow dam narrowed the channel of Min River and changed the flow direction of Min River, and outburst flood climbed up about 5 - $6 \mathrm{~m}$ and submerged the reconstructing Yinxiu town. The dammed lakes induced by the debris flow from Gaojia Gully blocked Min River in July 3, 2011 and the outburst flood scoured and ruined about $500 \mathrm{~m}$ road base so that the traffic from Yinxiu to Wenchuan was interrupted for 12 days and made huge loss. Furthermore, the 21 dammed lakes induced by debris flows on July 10, 2014 made more loss along Min River, especially the hazards on the highway of G213 and the Express Highway from Dujiangyan to Wenchuan.

Moreover, some big watersheds with over $5 \mathrm{~km}^{2}$, including the gullies of Yeniu, Taipingyi, Er and Luoquanwan, Cutou and Qipan also occurred large debris flows under the condition of rainstorm in 2013, which could block Min River and form bigger dammed lakes and further increase the risk of outburst flood. Step debris flow dammed lakes also prevent the recovery of water power plants along Min River due to water level increase and quantity of sediment deposition. For example, a dammed lake caused by hill-slope debris flow on July 10, 2013 at the southern exit of Chediguan tunnel not only submerged Futang Water Power Plant, but also bury some

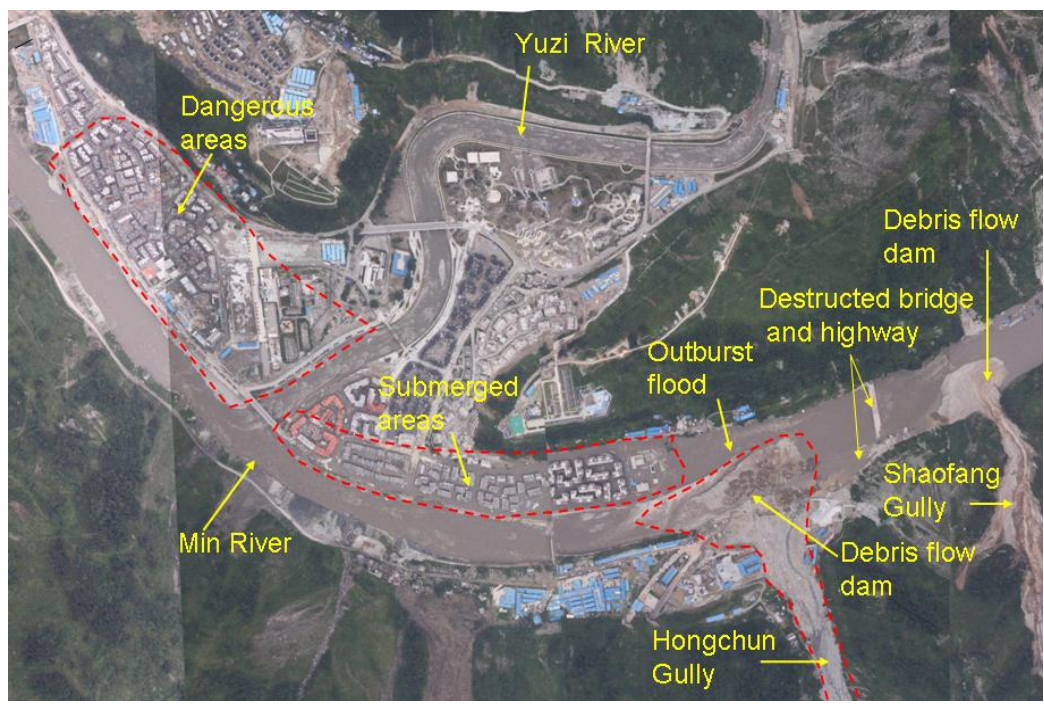

Figure 11. Yinxiu town threatened by 8.14 debris flows and outburst flood of dammed lakes. 
equipment due to a mass of sediment from upstream. Debris flows and the following dammed lakes will continuously endanger Yinxiu town and the highway from Yinxiu to Wenchuan, especially the high risk section where road bed is lower or close to the height of water level of dammed lakes or highway is easily scoured or destructed, for example, the highway Yinxiu to Laohuzui and from Gaojia Gully to Huaxi Gully.

\section{Conclusion and Countermeasures}

\subsection{Conclusion}

After the Wenchuan Earthquake, dammed lakes are easily produced by slope debris flow, gully debris flow and the combination of debris flow and landslides. Local rainstorm and intensive rain trigger numerous debris flows occurring in simultaneity, as a result, debris flow dammed lakes distribute step-by-step along river channel. Debris flow dammed lakes generally overflow and outburst along the front of deposition dam in decades minutes or several hours after dammed lake forming. The solid size components and the geomorphology of debris flow deposition dam make dammed lakes easily outburst partly but hardly completely. After the Wenchuan Earthquake, high-frequent debris flows continuously increase the magnitude of debris flow deposition dam so that the stability of a single dam further strengthens; however, the hazards and risks of step dammed lakes probably increase. Debris flow dammed lakes significantly change local eco-environment, raise local river bed, and impose huge dangers on inhabitants, highways, and lands by means of the scouring, burying and submerging of debris flow, outburst flood and lake water. Step-dammed lakes have produced continuously hazards and risk on habitants, reconstruction, highways, farmland, and water power stations along the rivers of Yuzixi, Min, Mianyuan, Tongkou and Qian, especially at the rivers of Yuzixi, Min and Mianyuan.

\subsection{Countermeasures}

Concerning the characteristics of debris flow dammed lakes and their problems on mitigating, the following suggestions were recommended:

1) The identification model for debris flow blocking river and the evaluation model of dammed lakes outburst, based on the dynamic mechanism of debris flow movement and sediment transportation, are required to be researched and developed to find potential hazard site and reduce risks.

2) The processes of debris flow dammed lakes, including formation, outburst and change, are suggested to deeply research based on field investigation and monitoring and stimulation experiment to discover dynamic mechanism of debris flow blocking river and dammed lake outburst, and provide valuable technical indexes for protecting construction design and risk evaluating.

3) For the Wenchuan Earthquake areas, the methodology and model of risk assessment for step debris flow dammed lakes are strongly recommended to explore and establish to identify risk area in advance, and provide reliable suggestions to reconstructing, regional mitigating and inhabitants' security.

4) For Min River, the hazards of debris flows and debris flow dammed lakes should be assessed to find the high-hazard areas to avoid. The reconstruction of inhabitant settlements, highways and waterpower stations are suggested to concern and avoid the hazards of debris flow dammed lakes. Moreover, the dangerous stepdammed lakes, located along Min River from Yingxiu to Miansi, should be treated.

\section{Acknowledgements}

This work was supported by the Key Program of National Natural Science Found of China (41030742) and the Program of National Natural Science Found of China (41171012). The authors are very grateful for the helps in field investigation from the other researchers of Institute of Mountain Hazards and Environments, Chinese Academy of Sciences.

\section{References}

[1] Hsu, Y.S. and Hsu, Y.H. (2009) Impact of Earthquake-Induced Dammed Lakes on Channel Evolution and Bed Mobility: Case Study of the Tsaoling Landslide Dammed Lake. Journal of Hydrology, 374, 43-55. http://dx.doi.org/10.1016/j.jhydrol.2009.05.020

[2] Chen, X.Q., Cui, P., Li, Y., et al. (2007) Changes in Glacial Lakes and Glaciers of Post-1986 in the Poiqu River Basin, Nyalam, Xizang (Tibet). Geomorphology, 88, 298-311. http://dx.doi.org/10.1016/j.geomorph.2006.11.012 
[3] Pánek, T., Hradecký, J., Smolková, V., et al. (2010) The Largest Prehistoric Landslide in Northwestern Slovakia: Chronological Constraints of the Kykula Long-Runout Landslide and Related Dammed Lakes. Geomorphology, 120, 233-247. http://dx.doi.org/10.1016/j.geomorph.2010.03.033

[4] Kershaw, J.A., Clague, J.J., Evans, S.G., et al. (2005) Geomorphic and Sedimentological Signature of a Two-Phase Outburst Flood from Moraine-Dammed Queen Bess Lake, British Columbia, Canada. Earth Surface Processes and Landforms, 30, 1-25. http://dx.doi.org/10.1002/esp.1122

[5] Komatsu, G., Arzhannikov, S.G., Gillespie, A.R., et al. (2009) Quaternary Paleolake Formation and Cataclysmic Flooding along the Upper Yenisei River. Geomorphology, 104, 143-164. http://dx.doi.org/10.1016/j.geomorph.2008.08.009

[6] Hermanns, R.L., Niedermann, S. and Ivy-Ochs, S. (2004) Rock Avalanching into a Landslide-Dammed Lake Causing Multiple Dam Failure in Las Conchas Valley (NW Argentina)_Evidence from Surface Exposure Dating and Stratigraphic Analyses. Landslides, 1, 113-122. http://dx.doi.org/10.1007/s10346-004-0013-5

[7] Schuster, R.L. and Alford, D. (2004) Usoi Landslide Dam and Lake Sarez, Pamir Mountains, Tajikistan. Environmental \& Engineering Geoscience, 10, 151-168. http://dx.doi.org/10.2113/10.2.151

[8] Bovis, M.J. and Jakob, M. (2000) The July 29, 1998, Debris Flow and Landslide Dam at Capricorn Creek, Mount Meager Volcanic Complex, Southern Coast Mountains, British Columbia. Canada Journal of Earth Science, 37, 13211334. http://dx.doi.org/10.1139/e00-042

[9] Clague, J.J. and Evans, S.G. (2000) A Review of Catastrophic Drainage of Moraine Dammed Lakes in British Columbia. Quaternary Science Reviews, 19, 1763-1783. http://dx.doi.org/10.1016/S0277-3791(00)00090-1

[10] Clague, J.J. and Evans, S.G. (1994) Formation and Failure of Natural Dams in the Canadian Cordillera. Geological Survey of Canada: Bulletin, 464, 35.

[11] Trauth, M.H. and Strecker, M.R. (1999) Formation of Landslide-Dammed Lakes during a Wet Period between 40,000 and 25,000 yr B.P. in Northwestern Argentina. Palaeogeography, Palaeoclimatology, Palaeoecology, 153, 277-287. http://dx.doi.org/10.1016/S0031-0182(99)00078-4

[12] Dai, F.C., Lee, C.F., Deng, J., et al. (2005) The 1786 Earthquake-Triggered Landslide Dam and Subsequent DamBreak Flood on the Dadu River, Southwestern China. Geomorphology, 65, 205-221. http://dx.doi.org/10.1016/j.geomorph.2004.08.011

[13] Chanson, H. (2005) The 1786 Earthquake-Triggered Landslide Dam and Subsequent Dam-Break Flood on the Dadu River, Southwestern China. Geomorphology, 71, 437-440. http://dx.doi.org/10.1016/j.geomorph.2005.04.017

[14] Chai, H.J., Liu, H.C. and Zhang, Z.Y. (1995) Landslide Dams Induced by Diexi Earthquake in 1933 and Its Environmental Effect. Journal of Geological Hazards and Environment Preservation, 6, 6-16.

[15] Cui, P., He, S.M., Yao, L.K., et al. (2011) Formation Mechanism and Risk Control of Geo-Hazards Induced by Wenchuan Earthquake. Science Press, Beijing.

[16] Cui, P., Chen, X.Q., Zhu, Y.Y., et al. (2011) The Wenchuan Earthquake (May 12, 2008), Sichuan Province, China, and Resulting Geohazards. Nature Hazards, 56, 19-36. http://dx.doi.org/10.1007/s11069-009-9392-1

[17] Huang, R.Q., Tang, C., Li, Y., et al. (2009) Geo-Hazards Assessment of the Wenchuan Earthquake. Science Press, Beijing.

[18] Cui, P., Zhu, Y.Y., Han, Y.S., et al. (2009) The 12 May Wenchuan Earthquake-Induced Landslide Lakes: Distribution and Preliminary Risk Evaluation. Landslides, 6, 209-223. http://dx.doi.org/10.1007/s10346-009-0160-9

[19] Liu, N., Zhang, J.X., Lin, W., et al. (2009) Draining Tangjiashan Barrier Lake after Wenchuan Earthquake and the Flood Propagation after the Dam Break. Science in China Series E: Technological Sciences, 52, 801-809. http://dx.doi.org/10.1007/s11431-009-0118-0

[20] You, Y., Liu, J.F., Chen, X.C., et al. (2010) Debris Flow and Its Characteristics of Subao River in Beichuan County after “5.12” Wenchuan Earthquake. Journal of Mountain Sciences, 28, 358-366.

[21] Cui, P., Zhuang, J.Q., Chen, X.C., et al. (2010) Characteristics and Countermeasures of Debris Flow in Wenchuan Areas after the Earthquake. Journal of Sichuan University (Engineering Science Edition), 42, 10-19.

[22] Tang, C., Zhu, J., Li, W.L., et al. (2009) Rainfall-Triggered Debris Flows Following the Wenchuan Earthquake. Bulletin of Engineering Geology and the Environment, 68, 187-194. http://dx.doi.org/10.1007/s10064-009-0201-6

[23] Yu, B. (2008) Research on the Calculating Density by the Deposit of Debris Flows. Acta Sedimentologica Sinica, 26, 789-796.

[24] He, Y.P. (2003) Influenced Debris Flow River Channel Changed Mountains. Ph.D. Thesis, Graduate Instituted Chinese Academy of Science, Chengdu. 
Scientific Research Publishing (SCIRP) is one of the largest Open Access journal publishers. It is currently publishing more than 200 open access, online, peer-reviewed journals covering a wide range of academic disciplines. SCIRP serves the worldwide academic communities and contributes to the progress and application of science with its publication.

Other selected journals from SCIRP are listed as below. Submit your manuscript to us via either submit@scirp.org or Online Submission Portal.
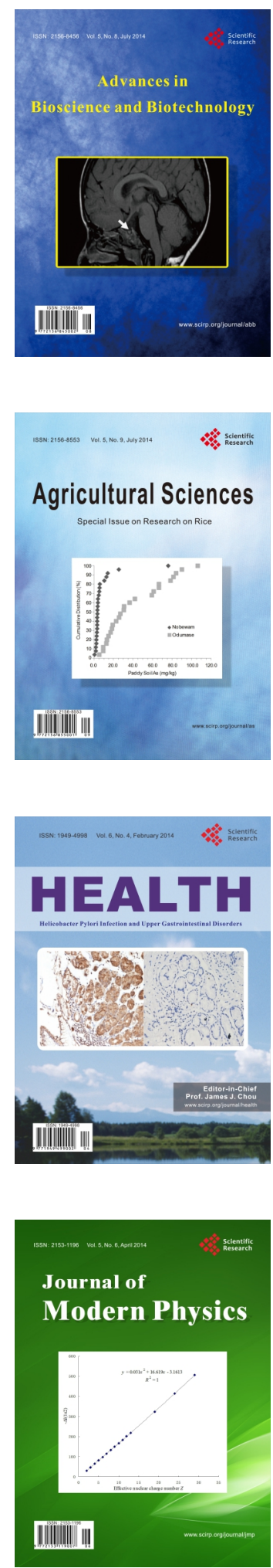
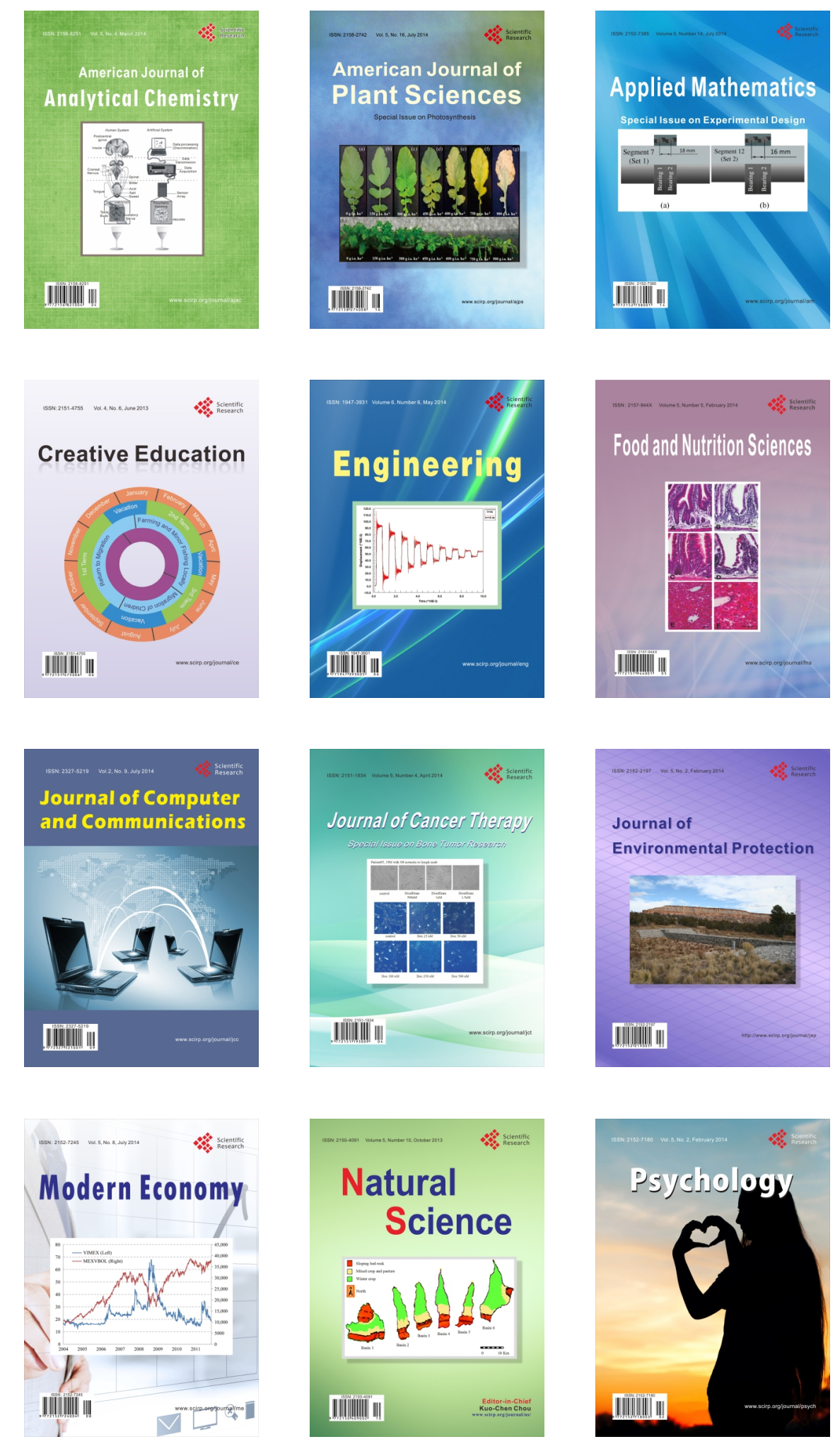